\title{
Sociocultural
}

\section{Learning Theories and Information Literacy Teaching Activities in Higher Education}

This article introduces collaborative learning models based on sociocultural learning theories and discusses their potential for developing more effective learning opportunities in information literacy teaching. As described in the research of Vygotsky and other theoreticians, sociocultural learning theories are learner-centered and provide insight into collaborative approaches to student learning. These theories take into account the social and cultural aspects of acquiring knowledge. Collaborative learning, as outlined in the literature review, is an effective means of increasing student achievement and cognitive development. Research also shows that in a community-of-learners, a learner's potential performance level is increased. In the last section of this article, several collaborative learning models are introduced: the jigsaw model, the reciprocal model, and collaborative peer groups, including problem-and resource-based learning. These models are then applied to information literacy teaching to demonstrate how collaborative learning approaches enhance the teaching. At the end, a comparison of the traditional library classroom and the community-of- learners environment is introduced; the article concludes that the information literacy community-of-learners is an effective learning environment to improve student learning.

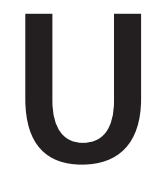

niversity libraries have a long history of teaching users to effectively use the library and library resources. Many library classes have been based on behavioral learning theories that focus on transmitting knowledge and skills to students in a well-structured manner. ${ }^{1}$ A survey from 272 American colleges and universities indicates that 68 percent of college and university students receive library instruction via the demonstration approach. ${ }^{2}$ In this learning environment, the teacher is the authority in the class, and the students do what the teacher instructs; knowledge is transmitted from the teacher to the students. The demonstration approach does not equip students with skills and competencies to function in a rapidly changing world. Students need to develop their critical thinking and lifelong learning skills, and teachers in higher education need to rethink peda-

\section{Li Wang}

Li Wang is Learning Services Manager, University of Auckland Library, New Zealand. Submitted for review February 19, 2006; accepted for publication June 12, 2006.
Reference \& User Services Quarterly, vol. 47, no. 2, pp. 149-158 (C) 2007 American Library Association. All rights reserved.

Permission granted to reproduce for nonprofit, educational use. 


\section{FEATURE}

gogies in information literacy teaching to support this.

Collaborative learning, based on sociocultural learning theories, provides learners with more effective learning opportunities. Students learn in a community-of-learners environment, where they act as community members. They engage in the class activities, interact with others and solve problems or complete tasks, think and talk about their thinking, and explore answers to the problems or tasks. The teacher acts as a motivator to encourage divergent answers and develop student critical thinking. In this learning environment, students' independent and reflective thinking skills will be improved. ${ }^{3}$

In this article, sociocultural learning theories and collaborative learning based on these theories are introduced. The idea of a community-of-learners in education and Vygotsky's zone of proximal development are then described. Finally, sociocultural learning theories and collaborative learning are applied to information literacy teaching in higher education by using different learning models.

\section{LITERATURE REVIEW- INFORMATION LITERACY TEACHING IN HIGHER EDUCATION}

According to Peacock, and Eisenberg, Lowe, and Spitzer, current information literacy teaching in higher education has four main types of approaches. These are intra-curricular, inter-curricular, extra-curricular and the standalone curricular courses: ${ }^{4}$

- Intra-curriculur: Information literacy is integrated into learning outcomes, learning activities, or assessments of an academic course or a teaching program, commonly via collaborative partnerships between academic and library staff. ${ }^{5}$

- Inter-curriculur: Information literacy is provided as an add-in session(s) for an academic course or program by the library in consultation with or at the request of individual academic staff. Normally, attendance is a requirement of the course or program. ${ }^{6}$

- Extra-curriculur: Information literacy is provided by the library outside of an academic curriculum, and attendance is voluntary. ${ }^{7}$

- Stand-alone: Information literacy is taught as an independent curricular course solely devoted to information literacy as part of the students' curricula. ${ }^{8}$ The stand-alone information literacy course is either taught as a selective course for credit or non-credit, or taught as a compulsory course as part of the general education program offered in a faculty or university. ${ }^{9}$

Rockman and Associates state that information literacy is no longer a library issue, but rather a critical campuswide issue, a learning issue, and an education issue. ${ }^{10}$ However, information literacy teaching has mainly been "developed by librarians, although this picture is gradually changing." ${ }^{" 11}$ Librarians in university libraries have had a long history of teaching library courses described variously as library instruction, bibliographic instruction, user or reader education, or sometimes as an information skills or information literacy program. University librarians have designed and established library courses to help students make effective use of library resources. Many of these library classes have been based on behavioral learning theories, which "are geared for efficiently transmitting information and basic skills to students in a well-organized manner." 12 The majority of college and university students receive library instruction via the traditional lecture or demonstration approach. ${ }^{13}$ Markless, who has twenty years' experience of teacher training for college, university, and health librarians, suggests that the teaching pedagogies and activities used in information literacy teaching in colleges and universities remain within a librarian- or teacher-centered approach. He states that:

when planning their teaching they [librarians] tend to focus on the information/skills that they wish to impart and structure sessions according to the logic of the content and in their own image. Sessions are very rarely planned with regard to principles of learning; . . . Most group sessions I have seen are characterised by teacher control of content, sequence and pace with a lot of student listening/watching/repeating the steps demonstrated. In addition the sessions are usually content heavy. ${ }^{14}$

Behavioral theories focus on directed instruction whereby a teacher transmits the knowledge to students in a well-organized manner. ${ }^{15}$ This forms the basis of traditional learning environments, where the teacher is the authority in the classroom and students do as the teacher instructs. In today's information-exploded world, students need to develop their critical thinking and lifelong learning skills to be able to access and evaluate information. They need to learn how to learn. The information literacy teaching focus in higher education needs to shift from recommending resources to critically selecting and evaluating resources; from how to use a particular database or a product to how to understand database process; from specific skills to general, transferable critical thinking and lifelong learning skills. The pedagogy based on behavioral theories is no longer accommodating the changes in information literacy teaching's focus. Both academic staff and librarians need to rethink pedagogies in information literacy teaching to meet the new challenges and develop students' critical thinking and lifelong learning skills.

In the last two decades, cognitive constructivist learning theories have been discussed and applied to information literacy teaching. ${ }^{16}$ These theories also have been used to design online information literacy tutorials and library computer classrooms. ${ }^{17}$ Cognitive constructivism focuses on students as individuals who "construct their own knowledge as they engage in the processes of interpreting and making sense of their classroom experience." ${ }^{18}$ It ac- 
knowledges that new knowledge always is constructed and built on previous knowledge. This is a learner-centered approach, where the teacher aims to elicit and understand what previous knowledge each individual has and helps him or her construct new knowledge on top of it. However, cognitive constructivism has been criticized for being too closely focused on the individual and ignoring the social and cultural context of learning. ${ }^{19}$

In recent years, sociocultural learning theories have appeared in library literature. Simons, Young, and Gibson have adopted sociocultural learning theories to develop a learning library where students interact with information resources as directed by faculty, complete assignments and study with peers, extend their knowledge at multiple levels, and seek connections and make meaning in more self-directed ways. ${ }^{20}$ Lazarow has briefly mentioned how she has applied Vygotsky's theory to her information literacy classes. ${ }^{21}$

Sociocultural learning theories are new to librarians. In library literature, little has been written about the principles of sociocultural learning theories and how to apply them to information literacy teaching activities. This article is intended to fill this gap by providing a brief overview of sociocultural learning theories and introducing a way in which they can be used to improve information literacy teaching.

\section{SOCIOCULTURAL LEARNING THEORIES AND COLLABORATIVE LEARNING}

Sociocultural learning theories take a learner-centered approach. Rather than viewing individuals, sociocultural theories take much greater account of the important roles that social relations, community, and culture play in cognition and learning. ${ }^{22}$

Sociocultural theories draw heavily on the work of Vygotsky as well as other later theoreticians, such as Lave, Lemke, Rogoff and Wertsch. ${ }^{23}$ Sociocultural theories claim that "learning, thinking and knowing are relations among people in activity in, with, and arising from the so- cially and culturally structured world."24 Vygotsky states that learning is embedded within social events, and social interaction plays a fundamental role in the improvement of learning..$^{25}$ Nuthall explains this with an example: "we understand a word by knowing how it is used, who uses it, and in what physical, social, and historical context it gets used. These are what we know when we "understand' a word rather than some mental entity called 'meaning."'26 Nuthall further states that "the words used to talk about mental processes refer to nothing more than the things we do in interaction with others when we are engaged in 'thought-related' activities." 27

When we view sociocultural theories within our real world, it is not hard to understand that learning is embedded in a social and cultural context. Moore explicitly explains that "children are surrounded by other people who interact and communicate with them. As they mature, they become part of other social networks (e.g. school, college, church, work, volunteer organizations) that continue to shape their thinking, learning and development through social interaction." ${ }^{28}$

\section{COLLABORATION AND COLLABORATIVE LEARNING}

Vygotsky says learning "appears twice: first on the social level, and later, on the individual level; first between people (interpsychology), and then inside the child (intrapsychology)." ${ }^{\prime 29}$ While Vygotsky's research was derived from working with and observing children, the important idea of the interrelationship of the outside and the inside, the social and cognitive processes, remains valid in adult learning. Without social and cultural interaction, "meaning of context and content would not exist. At the same time, the means and the transference from the unknown to the known would disappear. Internalization and learning would never occur." ${ }^{30}$ Therefore, collaboration "serves as a powerful vehicle of socialization in human psychological development."31

Collaborative learning is defined as "an instruction method in which students at various performance levels work together in small groups toward a common goal." 32 Vygotsky states that play plays a crucial role for children to move from one level of cognitive development to the next. When children interact physically and socially with an object, they conceptualize and express ideas, and their thinking transforms from the concrete to the abstract. ${ }^{33}$ This also can apply to the higher education learning situation. In the collaborative learning environment, students interact with learning tools and other members in group activities; they express and conceptualize their viewpoints and also listen to others in order to solve problems, to complete their tasks, or to generate new ideas.

Jennings and Di explain reasons why collaborative learning is more effective for increasing students' achievement and promoting their cognitive growth:

First, embedded in the idea of collaborative learning is what cognitive psychologists called "thinking out loud." In order to learn, children need the opportunity to think and talk about what they are doing. As they talk, they hear themselves, and others learn to recognize that which they understand or do not understand. Talking out loud helps children clarify their own thinking. Second, in a collaborative group, children are more focused on achieving the task, and thus spend much more time on the task in groups than when they would working individually. Third, the group situation forces children to engage in more higher-order thinking skills, such as application, analysis, synthesis, and evaluation. ${ }^{34}$

\section{COLLABORATIVE LEARNING ENVIRONMENT: A COMMUNITY-OF-LEARNERS}

According to sociocultural theories, learning is enhanced when knowledge 


\section{FEATURE}

is shaped by the activities and perspectives of the group. There will be an opportunity for more academically capable students to assist those who are less capable..$^{35}$ In adult learning situations, the teacher becomes the facilitator whose responsibility is to create a climate to foster collaborative learning. Both teachers and learners are participants in the learning process, "a sense of community is created, and knowledge is considered to be located in the community rather than the individual." ${ }^{36}$

In the community-of-learners, students take on the role of collaborative community members. They work toward their common goal — to complete the task. In achieving this goal, they will listen to others and engage in brainstorming and discussion in order to find the best solution to the question or to complete the task. Students are provided with opportunities to express themselves and take initiatives. Teachers are guides who can intervene if students ask questions or stray off the task in the class. In the community-oflearners, "the students also had opportunities to practise various social skills as they jointly worked out problems and co-constructed knowledge in the learning community." 37

\section{COLLABORATIVE LEARNING AND ZPD}

The zone of proximal development (ZPD) is defined by Vygotsky as "the distance between the actual developmental level as determined by independent problem solving and the level of potential development as determined through problem solving under adult guidance or in collaboration with more capable peers." ${ }^{38}$ In other words, ZPD refers to the distance between what a learner can do alone (actual performance level) and what a learner can do in collaboration with guidance or more advanced peers (potential performance level).

A study by Vygotsky demonstrates that "what is in the zone of proximal development today will be the actual development level tomorrow." ${ }^{139}$ Learning can be said to occur when assistance is offered at points in the ZPD at which performance requires assistance. Collaboration serves as a means of reaching a learner's potential performance level in the ZPD.

Nuthall has explained the three important characteristics of the transitional process that occurs in the learner's ZPD: "first, it involves interaction between participants of unequal expertise or knowledge; second, during the process of interaction, the child internalizes a transformed version of interaction; third, the outcome of the transitions that take place within the child's zone of proximal development is the ability of the learner to act and think independently." ${ }^{\prime 0}$

Hearn states that "development within the ZPD is preceded by two interdependent types of interaction that occur within this zone: scaffolding and intersubjectivity." Hearn goes on to describe scaffolding as "a metaphor for the interaction between an expert and a novice engaged in a problem solving task." ${ }^{41}$ In collaboration with others, the experienced peers (or teachers) offer scaffolded assistance to the learners and guide them to complete tasks or to solve problems that would not be competed or solved without the experienced peers' assistance. Hearn points out that successful scaffolding is "dependent on intersubjectivity, which is perceived as defining and limiting a task between individuals to arrive at a shared perspective or view of its goals and sub-goals." ${ }^{\prime 2}$ Full ZPD development depends upon full social interaction. In fact, this is considered to be crucial for successful ZPD interaction. Antón emphasizes that "in working within the ZPD, it is not the successful completion of the task that is of importance, but the higher cognitive process that emerges as a result of the interaction." ${ }^{\prime 3}$

Although the ZPD concept was originally constructed to describe child development in interaction with adults, "the current view of the ZPD has been expanded beyond novice-expert interaction." ${ }^{\prime 4}$ The important concept of the ZPD remains valid in tertiary student learning and enables us to understand that all learners are potentially better learners and to treat all of them as "able to offer new and valuable insights with respect to the issues being discussed in the classroom." ${ }^{45}$

According to sociocultural theories, learning happens through social interaction and is situated in specific cultural environments. Collaboration plays a key role in thinking and learning. Collaborative learning provides learners with the opportunity to interact with others and engage in solving problems or completing tasks, to think and talk about their thinking, and to explore answers to the problems or tasks. Let us look at how we can apply sociocultural theories to information literacy teaching activities.

\section{APPLYING SOCIOCULTURAL THEORIES TO INFORMATION LITERACY CLASSROOM TEACHING ACTIVITIES}

Jesús Lau, chair of the Information Literacy Section at the International Federation of Library Associations and Institutions (IFLA) states in the "International Guidelines on Information Literacy" (a draft proposal) that "A librarian not only needs to know what information literacy components to facilitate, but must be competent on how to facilitate knowledge (Pedagogy)." ${ }^{46}$ Pedagogy for information literacy teaching suggested by the American Library Association also has reflected the student-centered collaborative learning approach. ${ }^{47}$

Sociocultural learning theories provide us with an excellent framework to understand how students learn. Clearly the general tendency in information literacy teaching is to reduce the time teachers and librarians spend delivering lectures and increase the time spent interacting with students while students are doing learning tasks in the classroom. Instead of using traditional methods, we need to employ collaborative learning activities in information literacy teaching. Through collaborative activities and interactions, teachers and librarians can provide learners with effective assistance that will enable them to perform at higher levels than they would otherwise. 
An effective collaborative learning activity is critical to successful information literacy teaching, and it needs to be carefully planned. Vygotsky argues that effective tool use "is fundamental not only because it has helped them [learners] relate more effectively to their external environment but also because tool use has important effects upon internal and functional relationships within the human brain." ${ }^{48}$ In information literacy teaching, books, journals or journal articles, library catalogues, online databases, Internet resources, and so on all can be effectively used as learning tools in a collaborative environment to improve student learning. Below are some collaborative pedagogical learning models in information literacy teaching based on sociocultural theories.

\section{COLLABORATIVE LEARNING MODELS}

\section{Jigsaw Model}

The jigsaw method, developed by Aronson, is a collaborative classroom group learning model in which students are assigned part of a discussion topic to learn and subsequently to teach to others via reciprocal teaching. ${ }^{49}$ Anderson and Palmer have briefly described Aronson's jigsaw model:

The class is divided into small groups called jigsaw teams and the content material is divided into as many sections as there are team members. Each team is given one complete set of the material and individual team members are assigned their selection to study. Next, students break up into 'expert' or 'counterpart' groups which consist of all students who have the same section of information. In these expert groups students help each other learn the material and prepare a lesson for their original (jigsaw) teams. Once the students learn the material in the expert groups, they return to their jigsaw team to teach the material to their team- mates and to learn the remainder of the content. The technique is similar to that of putting together a jigsaw puzzle; thus it is called the jigsaw approach. ${ }^{50}$

The jigsaw model can be effectively used in information literacy teaching. For example, it can be used in information resources evaluation. The teacher prepares citation information (for example, two online books, two online articles, and two Web sites) and copies of the evaluation criteria, from criterion 1 to criterion 4 (see sidebar on following page; these criteria were compiled by the information literacy project team at the University of Auckland Library for postgraduate student information literacy courses).

In the class, all students are given the four evaluation criteria. The class is divided into jigsaw teams, with four members in each team. Each group is given a copy of citations that should lead them to full-text material online. After all jigsaw teams find the online books, articles, or Web sites, each student in each team is assigned one criterion group to study. Then students break up into "expert" groups: the criterion 1 group, criterion 2 group, and so on. All students who are assigned criterion 1 will join the criterion 1 expert group, and so on for all other expert groups.

In these expert groups, students help each other, learn the material, and prepare a lesson for their original (jigsaw) team. Once the students learn the material in the expert groups, they return to their jigsaw team to teach the material to their teammates and to learn the other criteria. The end result is students in all teams will learn how to evaluate books, journal articles, and Internet resources. Evaluation is a key component of information literacy. This activity fits within the realm of Australian and New Zealand Institute for Information Literacy (ANZIIL) Standard Three: "The information literate person critically evaluates information." ${ }^{51}$

The whole process in this activity presents the norms of collaboration among students. Students are encour- aged to take responsibility for their own learning and to share their expertise with others. The goal of these norms is to establish a classroom in which students will learn how to evaluate information in interaction with others. The jigsaw model offers an excellent opportunity for students to interact with criteria, resources, and peers. Learning occurs when students interact within their expertise group and their jigsaw team. Knowledge is constructed and internalized at each individual level, thus improving the learning process.

\section{Reciprocal Model}

The reciprocal model was originally developed by Palinscar and Brown to improve student reading comprehension. ${ }^{52}$ However, "the potential of reciprocal teaching has been widely explored in classroom teaching and learning across various classroom contexts." ${ }^{13}$ Brown et al. briefly explain the reciprocal model. Students are scaffolded in classroom interaction, supported by four pedagogic strategies related to text comprehension: questioning, clarifying, summarizing, and predicting. The tutor and a group of students take turns leading a discussion. The leader begins by asking a question and ending by summarizing the gist of what has been read. Questioning provides the impetus for discussion. At last, the leader asks for predictions about future content. In the ongoing interaction, the teacher and students share the expertise and responsibility of leading the discussion. In the flow of group discussion, the teacher gives guidance and provides feedback according to the varying needs of the participants. ${ }^{54}$

The reciprocal model can be used in information literacy teaching. The four pedagogic strategies in our situation can be changed to: questioning, feedback, summarizing, and reflecting. For example, the reciprocal model can be used in analyzing the main ideas of a research topic. Birks and Hunt have provided a good sample search question: "Does television promote aggression in children?" Ask the class to identify the main ideas (answers: 


\section{FEATURE}

\section{EVALUATION CRITERIA}

\section{Criterion 1: Authority}

- What are the author's credentials - educational background, occupation, position, past writings, or years of experience?

- Is the author associated with a reputable institution or organization, and what are the basic values or goals of the organization or institution?

- Is the book or article written on a topic in the author's area of expertise?

- Has your lecturer mentioned this author?

- Have you seen the author's name cited in other sources or bibliographies?

- Does the author provide contact details, such as an e-mail, postal address, or phone number?

- Who is responsible for the information? (Know the distinction between author and webmaster.)

- If it is a Web site, is the URL appropriate? What institution (company, organization, government, university, and so on) or Internet provider supports this information?

\section{Criterion 2: Currency}

- When was the book or article published?

- Is the source current or out of date for your topic?

- Are the cited references (if any) up to its publication date?

- Is this a first edition of this publication or not? If it is a Web site, do the pages indicate revision dates?

- Is the material primary or secondary in nature?

- Is the information presented cited correctly?

- If it a Web site, how up to date are the links (if any)?

- How many dead links are on the page?

- Are the links current or updated regularly?

- Is the information on the page outdated?

\section{Criterion 3: Purpose}

- What appears to be the purpose for the article or book? Does it inform, explain, or persuade?

- Is the information covered fact, opinion, or propaganda?

- Does the information appear to be valid and well-researched, or is it questionable and unsupported by evidence?

- Are the ideas and arguments advanced more or less in line with other works you have read on the same topic?

- Is the author's point of view objective and impartial? Is the language free of emotion-arousing words and bias?

- Who is the publisher?

\section{Criterion 4: Audience}

- What type of audience is the author addressing?

- Is the article or book aimed at a specialized or a general audience?

- Is the article or book aimed at a particular culture or gender?

- Is this source too elementary, too technical, too advanced, or just right for your needs?

- Is the article published in a popular magazine or a scholarly journal? television, children, aggression). Write the three main ideas (keywords) inside three giant bubbles on the white board and divide the class into small groups to brainstorm for words related to each keyword. More questions for students to discuss might be: "What are the synonyms (for example, TV)?" "What are more specific terms or things you see on TV (for example, cartoons, advertisements, movies, music videos)?" "What are the broader terms or bigger ideas (for example, media, entertainment industry, communications industry)?" "What are the related terms (for example, broadcasting, magazines, popular culture)?" Each group lists all possible search terms for television, children, and aggression. The teacher or librarian serves as facilitator, roving around the room, guiding students in choosing appropriate terms for the main ideas. ${ }^{55}$

Each group then will provide feedback to the class, and all the terms are written in each bubble on the white board. The teacher or group members summarize and add any terms that other groups may have missed, then analyze these terms and construct a search strategy. Through questioning, feedback, and summarizing, students are scaffolded in order to help them learn how to analyze topics and choose the best keywords to construct a search. Then, students will work in groups again to analyze another sample search question or their own search or assignment question to reflect on what they have just learned and to apply new knowledge to solve problems.

Through questioning, feedback, summarizing, and reflecting, students' cognition can be developed and new knowledge of topic analysis can be created and applied to any other topic. Reciprocal teaching "was deliberately designed to evoke the zone of proximal development within which novices could take on increasing responsibility for more expert roles. ${ }^{156}$

This activity fits within the realm of ANZIIL Standard One: "The information literate person recognizes the need for information." ${ }^{157}$ 


\section{Collaborative Peer Groups}

Collaborative peer groups are groups of equals who learn in a group to share ideas and experiences and to assist one another in solving problems and reach a common goal. According to sociocultural learning theories, the more students engage in group activities and interact with each other, the better they will learn. In a collaborative peer group, students share their views and perspectives with their peers so that they can explore different ways of approaching the learning objects and solving problems. They also can build on each other's contributions to reconstruct their new knowledge and, therefore, construct their own thinking process.

In order to make the peer group more collaborative and interactive, appropriate learning objects are very important. Due to the information literacy nature of resource seeking and evaluation, the problem- and resources-based learning models of collaborative peer groups can be used effectively in information literacy teaching.

\section{Peer Groups: Problem-based Learning Model}

According to Knowles, adult learners "tend to be problem-centered in their orientation to learning," rather than subject-centered. ${ }^{58}$ He suggests that "early in the session there would be a problem census or a diagnostic exercise through which the participants would identify the specific problems they want to be able to deal with more adequately." ${ }^{\text {99 }}$ Problem-based collaborative learning (PBL) is an effective way to teach information literacy.

One example of PBL is a problembased curricular course developed at the University of New Mexico, School of Medicine, where a librarian serves as a tutor in the PBL curriculum. The PBL tutorial process begins with a group of six students, who encounter a problem in the context of a simulated patient case:

María Rodríguez is a 42-year-old housewife who comes to your office with a one-year history of difficult breathing on exertion. The problem has become significantly worse over the last one or two months. Also, Mrs Rodríguez notes excessive fatigue and a sensation of chest pressure with physical activity. This morning she developed palpitations (sensation of irregular and fast heart rate) associated with a feeling of being short of breath while at rest (dyspnea). ${ }^{60}$

Students have no prior reading or lectures to prepare them for this encounter. The problem becomes the catalyst for motivating students to learn from one another initially, and later to learn through their search for appropriate information resources. The tutor serves as a facilitator who encourages students to see the need for knowledge and to extend the limits of their knowledge. Students discuss their ideas with their group and report their findings to the class. Each information resource is critically appraised according to its relevance to the patient described in the case and the quality of its information, including its accuracy, timeliness, and evidence-base.

Problem-based learning emphasizes collaborative learning. Students explore, solve problems, and understand the process of how the problems were solved, which encourages the deep learning approach rather than simply memorizing the solution. Through solving problems, students learn to effectively find information and critically evaluate information resources; therefore, their cognition is developed. PBL has been adopted in information literacy teaching in many university libraries in the United States and Australia in recent years. ${ }^{61}$

PBL's main focus is on the process of problem solving in a group rather than simply finding the solution to the problem. Once students have understood the problem, they need to use their existing knowledge and work as a group to interact with research tools and other peers to learn new knowledge in order to fill in the gaps and thus solve the problem; therefore, the students' ZPD is developed. PBL uses a student-centered learning approach and encourages development of students' critical thinking and lifelong learning skills. It can be used effectively in integrating information literacy into course curriculum because of its focus on searching and applying information as a means of answering questions in an academic course.

\section{Peer Groups: Resource-based Learning Model}

According to Breivik, problem-based learning actually "rests on the foundation of resource-based learning." 62 Resource-based learning is learning directly by engaging with resources. Resources could include "books, journals, television, online databases, radio, community experts, government agencies, the Internet, and $\mathrm{CD}$ ROMs .... all these sources become learning tools." ${ }^{13}$

It involves a collaborative learning environment where students utilize a variety of information resources to solve problems under the supervision of teachers and librarians and collaborating within their group. Information literacy offers an excellent opportunity for implementing resource-based learning, as indicated by Rader, who says that "librarians are uniquely qualified to partner with faculty to provide the resource expertise and instruction in their use." ${ }^{\circ 4}$

Resource-based learning has been used in information literacy teaching in United States university libraries. ${ }^{65}$ Brown and Krumholz give an example of a science librarian and a microbiology professor collaborating to offer resource-based learning. ${ }^{66}$ The librarian offers a one-hour, hands-on information literacy class in the use of a suite of the university library's databases. Then, the microbiology professor offers a fifty-minute lecture and gives students a list of articles selected from Science and Nature journals between 1982 and 1997, from which each student is assigned a refereed article to be presented in the class. Students need to perform 


\section{FEATURE}

a literature search to find two articles related to the one being presented. One article is required to be from a nonrefereed journal, and another from a refereed journal. The presenter submits a discussion of the major differences between the contents and the conclusions. Another student delivers an oral critique of the article and prepares a summary of their criticisms. To stimulate discussion, two other students then ask questions about the presented article. The faculty member grades these written and oral literacy events to evaluate the students' understanding of the material in the article. The librarian assesses their ability to locate, evaluate, and effectively use the information in the papers using checklists based on ACRL standards. ${ }^{67}$

This activity promotes both pedagogically advanced learning through the student-centered and resourcebased learning activity, as well as the interaction of resources, teacher, librarian, and students. Resource-based learning (RBL) enables librarians to use information resources as learning tools to facilitate student learning and assist students in solving problems or answering questions by applying information based on the resources. RBL is an ideal pedagogy for librarians and academic staff interested in working together to integrate information literacy into course curriculum.

\section{INFORMATION LITERACY COMMUNITY-OF-LEARNERS}

As discussed above, in the communityof-learners, the emphasis is not on the transference of skills or knowledge, but "on the collaborative use of mediational means, wherein teachers and children engage in exploratory talk and activity that assist them in the appropriation of skills, words, and knowledge as tools for reorganizing and understanding their experiences." ${ }^{68}$ Student learning will be improved within this specific social and cultural interactive environment.

Based on the role of students, teachers and content in the community-oflearners described by Brown and Asso- ciates and Imel, Wang has summarized and compared the traditional library classroom and the information literacy community-of-learners environment as shown in figure $1 .{ }^{69}$

In the information literacy community-of-learners, students and teachers and librarians are community members who play different roles than in the traditional library classroom. The traditional teacher's role as authority or transmitter of knowledge is reframed as knowledge co-learner. The traditional student's role as a knowledge receiver and note-taker also shifts to that of a more active problem solver, contributor, and discussant. The teacher is no longer a manager, but becomes the motivator in creating a climate fostering collaborative learning and the guide who aids the students' learning. According to sociocultural learning theories, a well-designed group learning activity in an information literate community-of-learners environment will enable students to develop their ZPD and improve their learning.

\section{CONCLUSION}

The focus of information literacy teaching needs to move from specific skills to general, transferable critical thinking and lifelong learning skills. When teach- ers and librarians move their teaching focus, they need to rethink pedagogies in information literacy teaching. Learning theories and information literacy standards should be used as the foundation of all information literacy learning design and activities. According to sociocultural learning theories, a collaborative learning activity is critical in teaching. A well-designed learning activity will engage and motivate students in learning and develop their critical thinking and lifelong learning skills. Sociocultural learning theories provide us with excellent models for developing collaborative learning activities that enable students to actively engage in the learning process, help teachers and librarians create an information literacy community-of-learners where students interact with each other, and help teachers and librarians understand ZPD so to help students reach their full potential developmental level.

\section{References}

1. Nancy H. Dewald, "Web-Based Library Instruction: What Is Good Pedagogy?" Information Technology and Libraries 18, no. 1 (1999): 26-32.

2. Donald A. Barclay and Darcie R. Barclay, "The Role of Freshman Writing in Academic Bibliographic Instruction," Journal of Academic Librarianship 20, no. 4 (1994): 213-17.

Figure 1. Traditional Library Classroom vs. the Community-of-learners environment

\begin{tabular}{|l|l|l|}
\hline $\begin{array}{l}\text { Role/Content/ } \\
\text { Environment }\end{array}$ & $\begin{array}{l}\text { Traditional Library } \\
\text { Classroom }\end{array}$ & $\begin{array}{l}\text { Community-of-Learners Envi- } \\
\text { ronment }\end{array}$ \\
\hline Role of student & $\begin{array}{l}\text { Listener, observer, note } \\
\text { taker; to do what teach- } \\
\text { er/ librarian instructs }\end{array}$ & $\begin{array}{l}\text { problem solver, contributor, } \\
\text { discussant; to be responsible for } \\
\text { their own learning }\end{array}$ \\
\hline Role of lecturer/librarian & $\begin{array}{l}\text { classroom manager, di- } \\
\text { dactic teacher, authority }\end{array}$ & $\begin{array}{l}\text { knowledgeable co-learner, guide } \\
\text { to aid the student's learning, mo- } \\
\text { tivator and class activity designer }\end{array}$ \\
\hline Content & $\begin{array}{l}\text { focus on the library, } \\
\text { highly constructed and } \\
\text { transmitted }\end{array}$ & $\begin{array}{l}\text { focus on information process, } \\
\text { learn via collaborative activities }\end{array}$ \\
\hline Environment & $\begin{array}{l}\text { competition, formal, } \\
\text { knowledge is transferred }\end{array}$ & $\begin{array}{l}\text { democratic, informal, } \\
\text { knowledge is created }\end{array}$ \\
\hline
\end{tabular}


3. Clara M. Jennings and $\mathrm{Xu} \mathrm{Di}$, "Collaborative Learning and Thinking: The Vygotskian Approach," in Vygotsky in the Classroom: Mediated Literacy Instruction and Assessment, L. Dixon-Krauss ed., 77-91 (White Plains, N.Y.: Longman, 1996).

4. Judy Peacock, "Information Literacy at Queensland University of Technology" (lecture), University of Auckland, New Zealand, Apr, 11, 2005; Michael B. Eisenberg, Carrie A. Lowe, and Kathleen L. Spitzer, eds., Information Literacy: Essential Skills for the Information Age (London: Libraries Unlimited, 2004).

5. Wendy Abbott and Deborah Peach, Building Info-Skills by Degrees: Embedding Information Literacy in University Study (ERIC Document Reproduction Service, ED447821, 2000); Kimberley M. Donnelly, "Building the Learning Library: Where Do We Start?" College \& Undergraduate Libraries 6, no. 2 (2000): 59-75; Hannelore B. Rader, "Information Literacy and the Undergraduate Curriculum," Library Trends 44, no. 2 (1995): 270-78; Patricia S. Breivik and Robert McDermand, "Campus Partnerships Building on Success," College \& Research Libraries News 65, no. 4 (2004): 210-13.

6. Kevin Simons, James Young, and Craig Gibson, "The Learning Library in Context: Community, Integration, and Influence," Research Strategies 17, no. 2/3 (2000): 123-32; Li Wang and Mary-Rose Russell, "A Good Mix or Far From Ideal? Information Literacy at the University of Auckland" (paper presented at Library and Information Association of New Zealand Aotearoa [LIAZNA] Conference, Auckland, New Zealand, 2004).

7. Wang and Russell, "A Good Mix"; Peacock, "Information Literacy."

8. Jesus Lau, "International Guidelines on Information Literacy-A Draft Proposal," www. library. unsw.edu.au/ psl/staff/ lesley/Alia//iflaguidelines043.doc (accessed Mar. 12, 2005).

9. Karen Visser, "Digital Immigrants Abroad: Learning the Language of E-learning" (paper presented at EDUCAUSE Australasia Conference, The Next Wave of Collaboration, Auckland, New Zealand, Apr. 5-8, 2005); Erika Behling, "UWParkside Information Literacy Tutorial," www.uwp.edu/departments/library/info lit/intro (accessed Mar. 13, 2005); Donnelly, "Building the Learning Library," 59-75; P. Callan et al., "Practice Makes Information Literacy Perfect: Models of Educational Collaboration at Queensland University of Technology," www.library .qut.edu.au/infoliteracy/publications/staff .jsp (accessed Feb. 14, 2005); Breivik and McDermand, "Campus Partnerships Building on Success," 210-13.

10. Ilene F. Rockman and Associates, Integrating Information Literacy into the Higher
Education Curriculum (San Francisco: Jossey-Bass, 2004).

11. Christine Bruce, The Seven Faces of Information Literacy (Adelaide: Auslib Pr., 1997), 42.

12. Dewald, "Web-Based Library Instruction," 27.

13. Barclay and Barclay, "The Role of Freshman Writing."

14. Sharon Markless, "Teaching Your Users: What You Really Need to Know," Legal Information Management 4 (2004): 221.

15. Dewald, "Web-Based Library Instruction," 26-32.

16. Elizabeth J. McNeer, "Learning Theories and Library Instruction," Journal of Academic Librarianship 17, no. 5 (1991): 294-97; Eileen E. Allen, "Active Learning and Teaching: Improving Postsecondary Library Instruction," Reference Librarian no. 51/52 (1995): 89-103; Bonnie Cheuk, "A Marketing Approach to the Design of Education Programs for Undergraduates," RSR: Reference Services Review 27, no. 1 (1999): 62-68; Esther S. Grassian and Joan R. Kaplowitz, Information Literacy Instruction: Theory and Practice (New York: Neal-Schuman, 2001); Jesus Lau, "International Guidelines."

17. Stefan A. Smith, "Designing Collaborative Learning Experiences for Library Computer Classrooms," College \& Undergraduate Libraries 11, no. 2 (2004): 65-83; Mark Emmons and Frances C. Wilkinson, "Designing the Electronic Classroom: Applying Learning Theory and Ergonomic Design Principles," Library Hi Tech 19, no. 1 (2001): 77; Dewald, "WebBased Library Instruction," 26-32; Doug Suarez, "Modeling and the Use of Graphics in Web Tutorials," College \& Research Libraries News 63, no. 2 (2002): 95.

18. G. Nuthall, "Understanding Student Thinking and Learning in the Classroom," in The International Handbook of Teachers and Teaching, B. J. Biddle, T. C. Good, and I. Goodson, eds., 681-768 (Dortrecht: Kluwer Academic Publ., 1997), 684

19. Nuthall, "Understanding Student Thinking and Learning in the Classroom," 681-768.

20. Simons, Young, and Gibson, "The Learning Library in Context."

21. Melanie Lazarow, "Constructing Information Literacy: A Vygotsky Approach" (paper presented at the 3rd International Lifelong Learning Conference: Whose Responsibility and What Is Your Contribution, Yeppon, Queensland, Australia, June 13-16, 2004).

22. Barbara Rogoff, Apprenticeship in Thinking: Cognitive Development in Social Context (New York: Oxford Univ. Pr., 1990).

23. Lev Vygotsky, Mind in Society: The Development of Higher Psychological Processes (Cambridge, Mass.: Harvard Univ. Press,
1978); Jean Lave, Cognition in Practice: Mind, Mathematics, and Culture in Everyday Life (Cambridge, Mass.: Cambridge Univ. Pr., 1988); Jay Lemke, Talking Science: Language, Learning, and Values (Norwood, N.J.: Ablex, 1990); James Wertsch, Mind As Action (New York: Oxford Univ. Pr., 1998).

24. J. Lave, "Situating Learning in Communities of Practice," in Perspectives on Socially Shared Cognition, L. B. Resnick, J. M. Levine, and S. D. Teasley, eds., 63-82 (Washington, D.C.: American Psychological Association, 1991), 67.

25. Vygotsky, Mind in Society.

26. Nuthall, "Understanding Student Thinking," 731.

27. Ibid., 732 .

28. Paula Moore, "Reading Recovery Teacher Training: Communities of Learners Engaged in Inquiry," Network News (Spring 1998): 7.

29. Vygotsky, Mind in Society, 57

30. Jennings and Di, "Collaborative Learning and Thinking," 78 .

31. Ibid., 79.

32. Anuradha A. Gokhale, "Collaborative Learning Enhances Critical Thinking," Journal of Technology Education 7, no. 1 (1995): 22.

33. Vygotsky, Mind in Society.

34. Jennings and Di, "Collaborative Learning and Thinking," 83.

35. Lev. S. Vygotsky, Thought and Language (Cambridge, Mass.: MIT Pr., 1986).

36. Susan Imel, Collaborative Learning in Adult Education (ERIC Document Reproduction Service, ED334469, 1991), 1.

37. Kristiina Kumpulainen and David Wray, Classroom Interaction and Social Learning: From Theory to Practice (New York: RoutledgeFalmer, 2002), 13-14.

38. Vygotsky, Mind in Society, 86.

39. Ibid.

40. Nuthall, "Understanding Student Thinking," 707.

41. Rosa Hearn, "A Sociocultural Perspective on Second Language Learning in a Core French Classroom: A Case Study (master's thesis, Ontario Institute for Studies in Education of the University of Toronto, 2002), 20.

42. Ibid., 21.

43. Marta Antón, "The Discourse of a LearnerCentered Classroom: Sociocultural Perspectives on Teacher-Learner Interaction in the Second-Language Classroom," The Modern Language Journal 83, no. 3 (1999): 304.

44. Ibid., 305

45. Gordon Wells, Changing Schools from Within: Creating Communities of Inquiry (Portsmouth, N.H: Heinemann, 1993), 9.

46. Lau, "International Guidelines."

47. ACRL Institute for Information Literacy, "Characteristics of Programs of Informa- 


\section{FEATURE}

tion Literacy That Illustrate Best Practices: A Guideline," www.ala.org/ala/acrl/acrl standards/characteristics.htm (accessed Feb. 12, 2005).

48. Vygotsky, Mind in Society, 133.

49. Elliot Aronson, The Jigsaw Classroom (Beverly Hills, Calif.: Sage, 1978).

50. Frances J. Anderson and Jesse Palmer, "The Jigsaw Approach: Students Motivating Students," Education 109, no. 1 (1988): 59.

51. Australian and New Zealand Institute for Information Literacy (ANZIIL), "Astralian and New Zealand Information Literacy Framework: Principles, Standards and Practice," www.anziil.org/resources/Info \%20lit\%202nd\%20edition.pdf (accessed Mar. 10, 2005), 16.

52. Aannemarie S. Palinscar and Ann L. Brown, "Reciprocal Teaching of Comprehension-Fostering and Comprehension-Monitoring Activities," Cognition $\varepsilon$ Instruction 1, no. 2 (1984): 117-67.

53. Kumpulainen and Wray, Classroom Interaction and Social Learning, 10.

54. Ann L. Brown et al., "Distributed Expertise in the Classroom," in Distributed Cognitions: Psychological and Educational Considerations, G. Salomon, ed., 188-228 (Cambridge, Mass.: Cambridge Univ. Pr., 1993).

55. Jane Birks and Fiona Hunt, Hands-on Information Literacy Activities (New York: Neal-Schuman, 2003).

56. Brown et al., "Distributed Expertise in the Classroom," 196.

57. ANZIIL, "Australian and New Zealand Information Literacy Framework," 12.
58. Malcolm Shepherd Knowles, The Modern Practice of Adult Education: From Pedagogy to Andragogy (New York: The Adult Education Co., 1970), 49.

59. Ibid.

60. Jonathan D. Eldredge, "The Librarian As Tutor/facilitator in a Problem-based Learning (PBL) Curriculum," Reference Services Review 32, no. 1 (2004): 55.

61. Linda Carder, Patricia Willingham, and David Bibb, "Case-based, Problem-based Learning: Information Literacy for the Real World," Research Strategies 18, no. 3 (2001): 181-90; Debora Cheney, "Problem-Based Learning: Librarians As Collaborators and Consultants," portal: Libraries and the Academy 4, no. 4 (2004): 495-508; Larry Spence, "The Usual Doesn't Work: Why We Need Problem-Based Learning," portal: Libraries and the Academy 4, no. 4 (2004): 485-93; D. Chambers, "Using Problem Based Learning to Hone Information Literacy and Independent Learning Skills" (paper presented at the 2nd International Lifelong Learning Conference, Yeppoon, Central Queensland, Australia, June 16-19, 2002).

62. Patricia Senn Breivik, Student Learning in the Information Age (Phoenix, Ariz.: Oryx Pr., 1998), 25.

63. Ibid.

64. Hannelore B. Rader, "Faculty-Librarian Collaboration in Building the Curriculum for the Millennium-The US Experience" (paper presented at 64th IFLA General Conference, Amsterdam, August 16-21, 1998), www.ifla.org/IV/ifla64/040-112e .htm (accessed Mar. 11, 2005).
65. Bruce, The Seven Faces of Information Literacy; Sandra Parker and Maureen Jackson, "The Importance of the Subject Librarian in Resource Based Learning: Some Findings of the IMPEL2 Project," Education Libraries Journal 41, no. 2 (1998): 21-26; Breivik, Student Learning in the Information Age; Brown and Krumholz, "Integrating Information literacy," 111-23.

66. Brown and Krumholz, "Integrating Information Literacy," 111-23.

67. Association of College and Research Libraries, "Information Literacy: Competency Standards for Higher Education," Teacher Librarian 28, no. 3 (2001): 16-22.

68. Daniel P. Shepardson, "Learning Science in a First Grade Science Activity: A Vygotskian Perspective," Science Education 83, no. 5 (1999): 622

69. Brown, et al., "Distributed Expertise," 203-08; Imel, Collaborative Learning; Li Wang, "Information Literacy Courses-A Shift From a Teacher-centred to a Collaborative Learning Environment" (paper presented at the 4th International Lifelong Learning Conference: Partners, Pathways, and Pedagogies, Yeppoon, Queensland, Australia, June 13-16, 2006), www.researchspace .auckland.ac.nz/bitstream/2292/438/1/ lifelongConf\%202006Paper37-final.pdf (accessed July 31, 2007). 